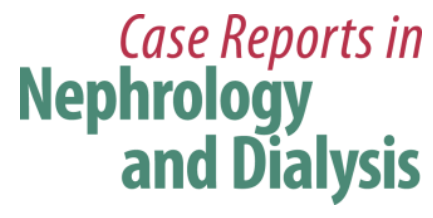

Case Rep Nephrol Dial 2018;8:268-276

DOI: 10.1159/000495106

Published online: December 11, 2018

(C) 2018 The Author(s)

Published by S. Karger AG, Basel

www.karger.com/cnd

This article is licensed under the Creative Commons Attribution-NonCommercial 4.0 International License (CC BY-NC) (http://www.karger.com/Services/OpenAccessLicense). Usage and distribution for commercial purposes requires written permission.

\title{
Lumbar Artery Bleed as a Complication of Percutaneous Renal Biopsy and a Proposed Workflow for Massive Bleeding
}

\author{
Clara Lee Ying Ngoh ${ }^{a}$ Bernard Boon Kee Wee ${ }^{b}$ Weng Kin Wong \\ aDepartment of Medicine, National University Health System, Singapore, Singapore; \\ ${ }^{b}$ Department of Diagnostic and Interventional Radiology, National University Health \\ System, Singapore, Singapore
}

\section{Keywords}

Lumbar artery $\cdot$ Renal biopsy · Haemorrhage

\begin{abstract}
Injuries to extrarenal arteries caused by percutaneous biopsy needles are very rare but highly lethal due to delay in recognition. Here we report the case of an inadvertent lumbar artery puncture after native renal biopsy and provide a literature review and a proposed workflow for management of massive bleed after renal biopsy. This case highlights evidence-based management considerations regarding massive bleed after renal biopsy, including the first-line imaging modality and the need to consider extrarenal site bleed. While angiographic embolization is an effective method of control of haemorrhage, surgical exploration is required in a proportion of cases for control of bleeding. Centre-specific workflows should be adopted to minimize the mortality and morbidity associated with massive bleed after renal biopsy.
\end{abstract}

(C) 2018 The Author(s)

Published by S. Karger AG, Basel

1 E Kent Ridge Road, Level 10 NUHS Tower Block

Singapore 119228 (Singapore)

E-Mail weng_kin_wong@nuhs.edu.sg 


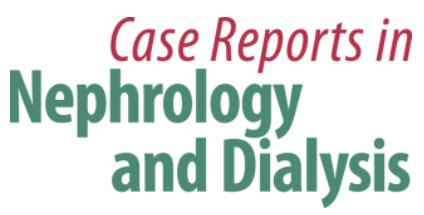

Case Rep Nephrol Dial 2018;8:268-276

DOI: 10.1159/000495106

(c) 2018 The Author(s). Published by S. Karger AG, Base
www.karger.com/cnd

Ngoh et al.: Lumbar Artery Bleed as a Complication of Kidney Biopsy

\section{Introduction}

Clinically significant complications following percutaneous native renal biopsies range from 0.4 to $8 \%$, with $1-5 \%$ of cases with perirenal haematoma requiring blood transfusion [1, 2]. Puncture of other organs or viscera is exceptional, and a delay in its recognition can increase morbidity. We present the case of an elderly female with inadvertent lumbar artery bleeding after percutaneous renal biopsy, and a proposed workflow for suspected massive bleeding after renal biopsy.

\section{Case Report}

A 72-year-old Malay female presented with generalized abdominal pain and hypertensive urgency. She had a significant past medical history of type 2 diabetes mellitus on metformin $250 \mathrm{mg}$ daily, hypertension on nifedipine prolonged-release $60 \mathrm{mg}$ every morning, and hyperlipidaemia on atorvastatin $20 \mathrm{mg}$ every night. A physical examination revealed that she was obese (BMI $30.5 \mathrm{~kg} / \mathrm{m}^{2}$ ); other vital signs included blood pressure at 234/96 mm $\mathrm{Hg}$ and an irregular pulse at 87 beats/min. She was non-oedematous, with clear lungs on auscultation. Her abdomen was soft with severe left hypochondriac tenderness. Cardiac, neurological, and fundoscopic examinations were unremarkable.

The results of the initial laboratory investigations are summarized in Table 1, showing normal renal function, hypoalbuminaemia, and heavy proteinuria. Computed tomography scanning of the abdomen done for persistent abdominal pain showed numerous ill-defined hypodensities in the posterior-inferior spleen with poor opacification of the splenic arterial branches, which were reported as possible splenic infarcts. The kidneys were of normal size. Two days later, despite blood pressure control to $140 / 95 \mathrm{~mm} \mathrm{Hg}$, the patient experienced oliguria $(0.2 \mathrm{~mL} / \mathrm{kg} / \mathrm{h})$ with a rise in serum creatinine to $199 \mu \mathrm{mol} / \mathrm{L}$.

Percutaneous native renal biopsy was performed in view of her rapidly worsening renal function. Biopsy was done under real-time ultrasound guidance (Toshiba Viamo, Japan) with a 16-G automated spring-loaded biopsy gun, with the length for the sample notch being 1.6 $\mathrm{cm}$ and the possible penetration depth $22 \mathrm{~mm}$ (Bard Biopsy Systems, USA). The left kidney was biopsied. Two specimens were obtained in two attempts. Systolic blood pressure remained $<160 \mathrm{~mm} \mathrm{Hg}$ throughout the procedure.

Six hours after the procedure, the patient was noted to be stertorous on the ward with cool peripheries and left flank distension. Blood pressure remained stable at 130/80 $\mathrm{mm} \mathrm{Hg}$, but haemoglobin had dropped to $6.8 \mathrm{~g} / \mathrm{dL}$. An urgent renal artery angiogram was performed. This revealed focal contrast extravasation from the 4th left lumbar artery at the 4th lumbar vertebra, which was cannulated with a microcatheter (Fig. 1). Embolization was then performed with $2 \mathrm{~mm} \times 3 \mathrm{~cm}$ coils. Transfusion of 4 units of packed red blood cells was performed, which improved her haemoglobin to $10 \mathrm{~g} / \mathrm{dL}$.

Despite successful intervention at the bleeding lumbar artery, the patient deteriorated clinically $4 \mathrm{~h}$ after embolization, with a poor conscious state and high-anion gap decompensated metabolic acidosis (peak lactate $9.4 \mathrm{mmol} / \mathrm{L}$ ). She went on to require intubation although no inotropic support was required. Repeat haemoglobin revealed a drop again to 6.5 $\mathrm{g} / \mathrm{dL}$. A repeat renal, lumbar, and mesenteric angiogram did not show evidence of active re- 


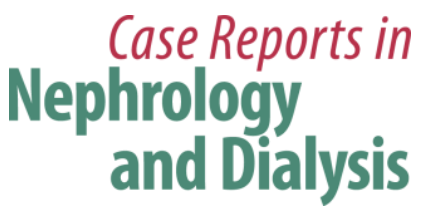

\begin{tabular}{l|l} 
Case Rep Nephrol Dial 2018:8:268-276 \\
\hline DOI: 10.1159/000495106 & $\begin{array}{l}\text { (c) } 2018 \text { The Author(s). Published by S. Karger AG, Basel } \\
\text { www.karger.com/cnd }\end{array}$
\end{tabular}

bleed or new sources of bleeding. Computed tomography scanning of the abdomen and pelvis showed a $12.1 \times 8.2 \times 7.5 \mathrm{~cm}$ haematoma in the left posterior pararenal space with no active contrast extravasation (Fig. 2). A vascular surgery team was contacted for standby explorative surgery. Fortunately, the patient's clinical condition and haemoglobin stabilized, and she was extubated $12 \mathrm{~h}$ later.

The renal biopsy eventually returned from the pathologist with a diagnosis of diabetic nephropathy with $30 \%$ interstitial fibrosis and tubular atrophy. In total, the patient received a transfusion of 6 units of packed red blood cells. The biopsy bleed was complicated by stage 3 oliguric acute kidney injury (AKI) due to the contrast load but did not require renal replacement therapy [3]. It was further complicated by subcortical strokes in the left corona radiata secondary to hypoperfusion. The patient was discharged 45 days after initial admission.

\section{Discussion}

Injuries to extrarenal arteries by percutaneous biopsy needles are very rare. We performed a systematic search on the following databases: Embase via PubMed (1948 to June 2018), MEDLINE via PubMed (1980 to June 2018), and CINAHL via EBSCO (1926 to June 2018); this revealed only 7 reported cases of lumbar artery injury following percutaneous native renal biopsy (Table 2) [4-10]. The patients' ages ranged from 35 to 70 years, with serum creatinine ranging from 65 to $230 \mu \mathrm{mol} / \mathrm{L}$, and they had a normal coagulation profile. Separately, there have been solitary reports of injury to the mesenteric artery, intercostal artery, and abdominal aorta after native renal biopsy [11-13].

Four pairs of lumbar arteries arise from the aorta. The anterior branches of these lumbar arteries run dorsal to the kidney and supply muscles such as the quadratus lumborum and sacrospinalis, as well as the skin of the flank. These muscular branches running dorsally to the kidney are vulnerable to injury from the biopsy needle. Our case is unusual because the lacerated 4th lumbar artery runs a distance below the left kidney's lower pole. In addition, lumbar arteries are too small to be visualized on standard ultrasound or by Doppler techniques, making this bleed virtually undetectable.

No obvious risk factors for lumbar artery bleeding were found in this case series, although the small sample size is a notable limitation. Manno et al. [13] showed in an Italian prospective study that the predictors of bleeding complications in ultrasound-guided percutaneous renal biopsy included female gender, older age, and higher baseline partial thromboplastin time (102 vs. $100 \mathrm{~s}$; unadjusted odds ratio 1.26; confidence interval 0.68-0.94). A meta-analysis identified that predictors of erythrocyte transfusion included 14-G needles (compared to 16or $18-G$ needles), a mean creatinine $>170 \mu \mathrm{mol} / \mathrm{L}$ (compared to $<170 \mu \mathrm{mol} / \mathrm{L}$ ), AKI and a prebiopsy haemoglobin level $<12 \mathrm{~g} / \mathrm{dL}$ (compared to $>12 \mathrm{~g} / \mathrm{dL}$ ) [1]. Obesity was associated with a lower bleeding risk than having a normal BMI [14]. Based on the above, our patient had an increased bleeding risk. Separately, we hypothesize that vessel calcification in elderly patients increases the risk of bleeding and thus contributed to our patient's subsequent lactemic response to intravascular volume depletion.

Virtually all of the cases with lumbar artery bleeding presented with clinical shock with a palpable haematoma [4-10]. This is also true with intrarenal artery bleeding. In such instances, an urgent contrast computed tomography angiogram facilitates a minimally invasive 


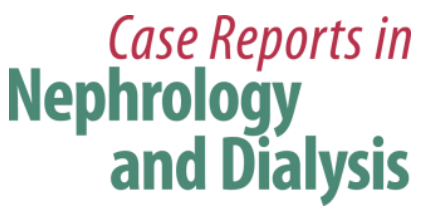

\begin{tabular}{l|l} 
Case Rep Nephrol Dial 2018:8:268-276 \\
\hline DOI: 10.1159/000495106 & $\begin{array}{l}\text { (c) } 2018 \text { The Author(s). Published by S. Karger AG, Basel } \\
\text { www.karger.com/cnd }\end{array}$
\end{tabular}

diagnosis and rapid therapeutic effect, via embolization. We hence believe that percutaneous renal biopsies should be performed in or near centres with round-the-clock angiographic support.

Five $(71.4 \%)$ of the 7 patients with lumbar artery bleeding had $>1$ bleeding site $[4-7,10]$. There were 2 reports where the presence of intrarenal bleeding sites was misleading and resulted in a delay of 20 and $48 \mathrm{~h}$, respectively, before the laceration of the lumbar artery was identified $[4,6]$. Nephrologists and radiologists must hence be suspicious of dual or multisite bleeding when a patient's clinical condition unexpectedly deteriorates despite apparent successful embolization of the bleeding artery. This was why an extensive angiogram involving renal, lumbar, and mesenteric vessels was performed when our patient deteriorated after lumbar artery embolization.

Despite the initial success of embolization therapy, it is worth remembering that 2 (28.6\%) of the 7 patients in this case series had failed angiographic interventions and required surgery [4, 8]. Similarly, Breyer et al. [15] reported that $12 \%$ of biopsy bleeds eventually required open surgical repair; $10 \%$ of the patients underwent total nephrectomy, and $2 \%$ underwent partial nephrectomy. In addition, lumbar angiography carries the risk of spinal cord infarction if the catheter tip is directed into the radicular medullary artery which supplies the spinal cord. Infarction of paraspinal muscles has been reported in 2 patients [4]. The radicular medullary artery most often arises from the left at the level of 9th-12th intercostal artery (65\%), but variations of its origin are from lumbar arteries at the level of L1 or L2 (10\%), intercostal arteries at the level of T5-T8 (15\%), and from the right side (10\%). Embolization should only be done after considering all these variations in origin of the artery [4].

Based on the evidence that has been presented, we propose a workflow for suspected massive bleeding after percutaneous native renal biopsy (Fig. 3). We define massive bleeding by clinical deterioration, such as hypotension, altered mental status, acute onset of pain, and/or a palpable haematoma, which usually occurs in the first $8 \mathrm{~h}$ after biopsy. Similar workflows should be adopted at all centres to expedite diagnosis and therapeutics and clearly define when surgical exploration should be considered. This in turn will reduce mortality and morbidity associated with massive post-biopsy bleeds.

\section{Conclusions}

Bleeding from a lumbar artery after percutaneous renal biopsy is a rare but potentially lethal complication. There should be a high suspicion for multiple bleeding sites if a patient continues to deteriorate after apparently successful angiographic embolization. While angiographic embolization is an effective method of control of haemorrhage, surgical exploration is required in a proportion of cases for control of bleeding. Centre-specific workflows should be adopted to minimize the mortality and morbidity associated with massive post-biopsy bleeds.

\section{Statement of Ethics}

The authors have no ethical conflicts to disclose. 


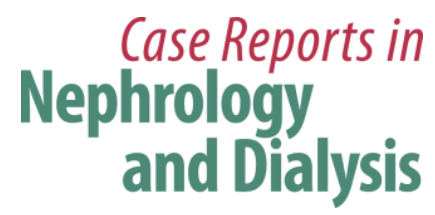

Case Rep Nephrol Dial 2018;8:268-276

\section{Disclosure Statement}

The authors have no conflicts of interest to declare.

\section{Author Contributions}

C.L.Y.N. and W.K.W. contributed to patient care and writing of the manuscript. B.B.K.W. contributed to patient care and editing of the manuscript and provided the radiology images.

\section{References}

1 Corapi KM, Chen JL, Balk EM, Gordon CE. Bleeding complications of native kidney biopsy: a systematic review and meta-analysis. Am J Kidney Dis. 2012 Jul;60(1):62-73.

2 Madaio MP. Renal biopsy. Kidney Int. 1990 Sep;38(3):529-43.

3 KDIGO Clinical Practice Guideline for Acute Kidney Injury. Kidney Int Suppl. 2012;2(Suppl 1).

4 Jamison MH, Coward RA. Severe haemorrhage from a lumbar artery as a complication of percutaneous renal biopsy. Postgrad Med J. 1985 Jan;61(711):69-70.

5 Whittier WL. Complications of the percutaneous kidney biopsy. Adv Chronic Kidney Dis. 2012 May;19(3):179-87.

6 Wall B, Keller FS, Spalding DM, Reif MC. Massive hemorrhage from a lumbar artery following percutaneous renal biopsy. Am J Kidney Dis. 1986 Mar;7(3):250-3.

7 Janík V, Martínek V, Pádr R, Lisy J, Neuwirth J, Pafcugová J, et al. Embolization of lumbar artery due to retroperitonal bleeding following renal biopsy. Nephrol Dial Transplant. 2005 Apr;20(4):820-2.

8 Krejčí K, Černá M, Žamboch K, Orság J, Klíčová A, Zadražil J. Late rupture of lumbar artery as an unusual complication after renal biopsy - Case report. Urol Int. 2017;98(1):112-4.

9 Pathan AM, Gandhi BV, Deshpande RV, Marar S, Vyahalkar SV. Lumbar artery embolization for control of bleeding after percutaneous renal biopsy. Med Surg Urol. 2016;5(1):143-5.

10 Galloway DC, Tytle T. Laceration of a mesenteric artery: unusual complication of percutaneous renal biopsy. South Med J. 1980 Oct;73(10):1413-4.

11 Herrero JC, Morales E, Carreño A, Domínguez-Gil B, González E, Ortiz M, et al. Severe haemorrhage and retroperitoneal haematoma secondary to renal biopsy. Nephrol Dial Transplant. 2001 May;16(5):1078-9.

12 Katopodis KP, Katsios CG, Koliousi EL, Nastos DS, Siamopoulos KC. Life-threatening hemorrhage from abdominal aorta following a percutaneous renal biopsy. Clin Nephrol. 2006 Jun;65(6):446-8.

13 Manno C, Strippoli GF, Arnesano L, Bonifati C, Campobasso N, Gesualdo L, et al. Predictors of bleeding complications in percutaneous ultrasound-guided renal biopsy. Kidney Int. 2004 Oct;66(4):1570-7.

14 Lees JS, McQuarrie EP, Mordi N, Geddes CC, Fox JG, Mackinnon B. Risk factors for bleeding complications after nephrologist-performed native renal biopsy. Clin Kidney J. 2017 Aug;10(4):573-7.

15 Breyer BN, McAninch JW, Elliott SP, Master VA. Minimally invasive endovascular techniques to treat acute renal hemorrhage. J Urol. 2008 Jun;179(6):2248-52. 


\section{Case Reports in Nephrology and Dialysis}

Case Rep Nephrol Dial 2018;8:268-276
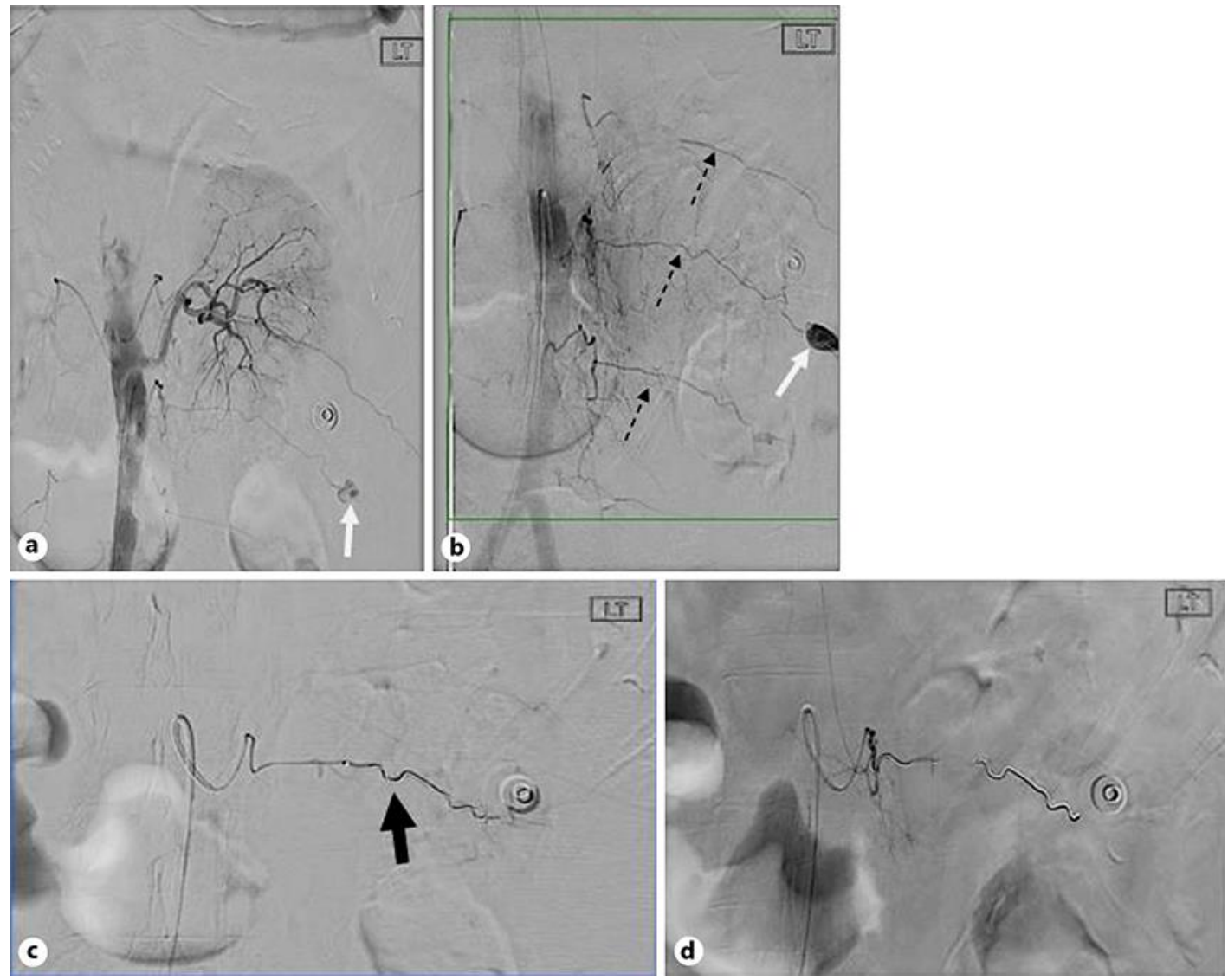

Fig. 1. a The patient's first kidney angiogram, demonstrating no obvious bleed from the intrarenal intraarterial tree. However, a blush (white arrow) was noted from the lumbar artery. b Flush aortography was next performed, which demonstrate the left lumbar artery (dashed black arrows) and the lumbar artery bleeding point (white arrow). c An embolization coil (bold black arrow) was deployed via a microcatheter within the feeding artery. $\mathbf{d}$ The post-coiling angiogram shows the correction of the flow beyond the coil. 


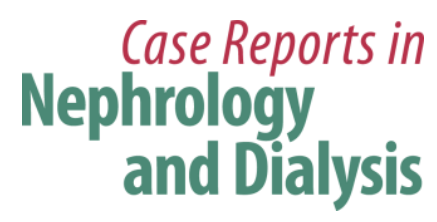

Case Rep Nephrol Dial 2018;8:268-276

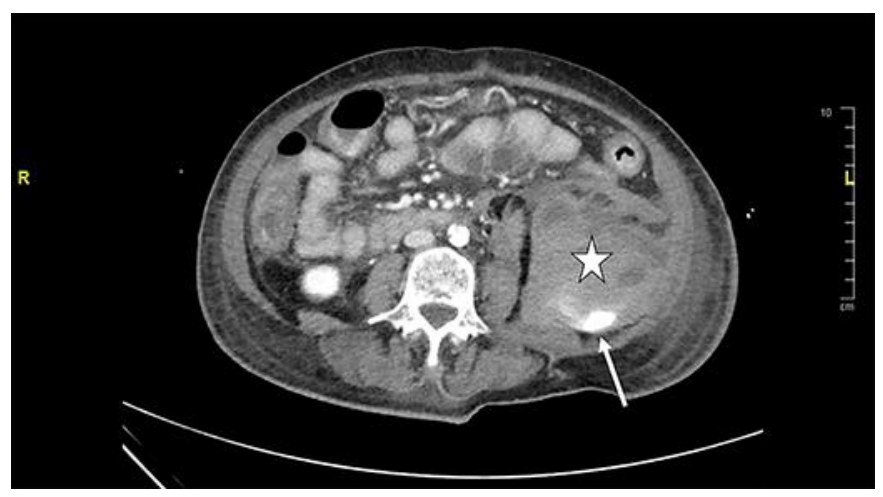

Fig. 2. A second catheter angiogram was made due to the patient's clinical deterioration. On the transverse section of the abdomen, note the large haematoma (star) with retroperitoneal layering of the residual contrast (white arrow) from the first catheter angiogram.

\section{Suspected massive bleed}

Defined by any one of the following: hypotension, altered mental state, pain, palpable haematoma. Usually occurring within $8 \mathrm{~h}$ post biopsy

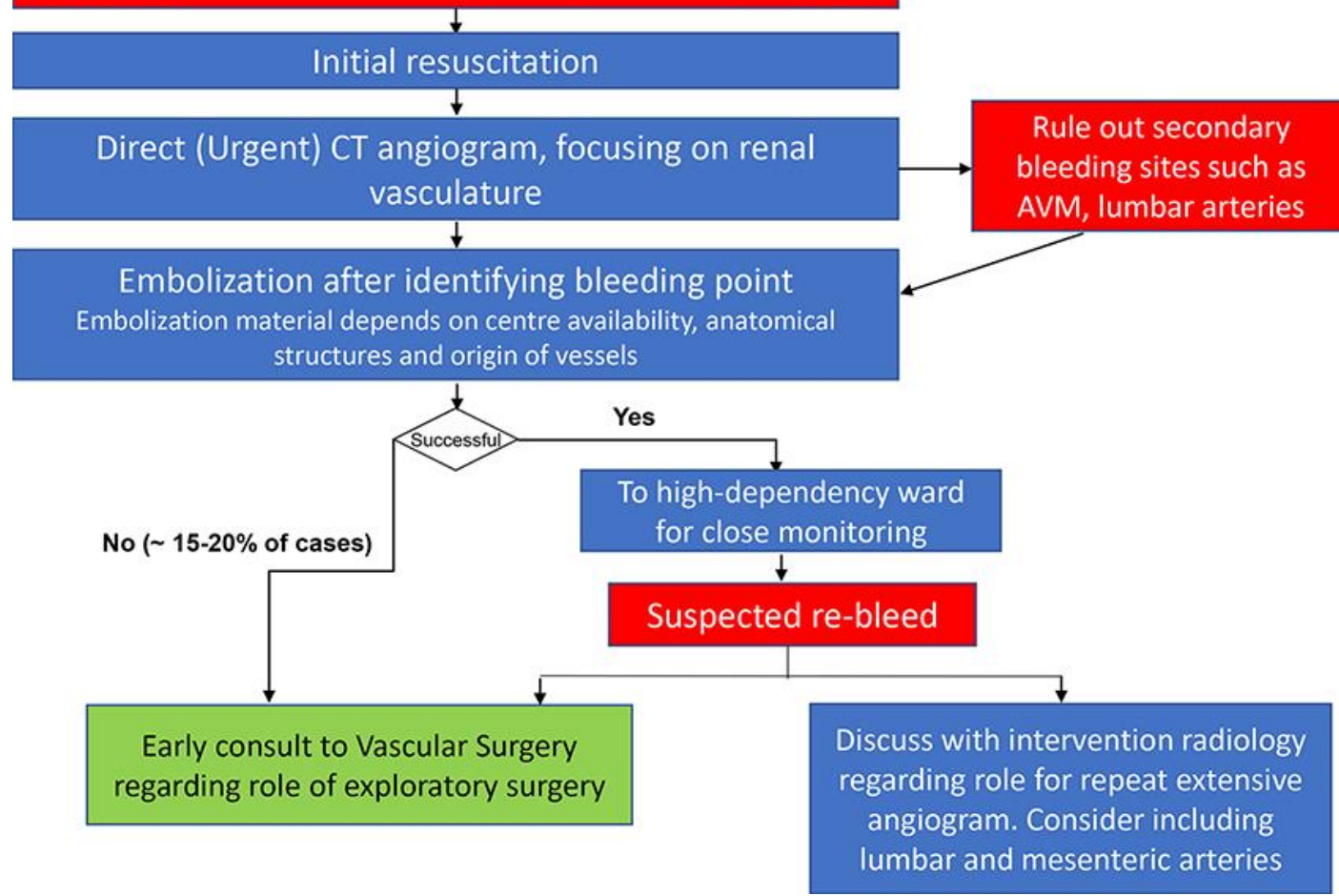

Fig. 3. Proposed workflow for suspected massive post-biopsy bleed. 


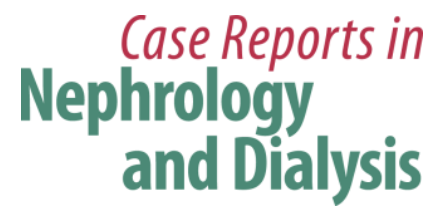

\begin{tabular}{l|l} 
Case Rep Nephrol Dial 2018;8:268-276 \\
\hline DOI: 10.1159/000495106 & $\begin{array}{l}\text { (c) 2018 The Author(s). Published by S. Karger AG, Basel } \\
\text { www.karger.com/cnd }\end{array}$ \\
\hline
\end{tabular}

Table 1. Results of the initial laboratory investigations

\begin{tabular}{lll}
\hline & Result & Normal range \\
\hline Blood & & \\
Haemoglobin & $12.8 \mathrm{~g} / \mathrm{dL}$ & $11.4-14.7 \mathrm{~g} / \mathrm{dL}$ \\
Platelets & $335 \times 10^{9} / \mathrm{L}$ & $164-387 \times 10^{9} / \mathrm{L}$ \\
Sodium & $134 \mathrm{mmol} / \mathrm{L}$ & $135-145 \mathrm{mmol} / \mathrm{L}$ \\
Potassium & $3.2 \mathrm{mmol} / \mathrm{L}$ & $3.5-5 \mathrm{mmol} / \mathrm{L}$ \\
Creatinine & $87 \mu \mathrm{mol} / \mathrm{L}$ & $50-90 \mu \mathrm{mol} / \mathrm{L}$ \\
Urea & $5.2 \mathrm{mmol} / \mathrm{L}$ & $2.0-4.0 \mathrm{mmol} / \mathrm{L}$ \\
Albumin & $24 \mathrm{~g} / \mathrm{L}$ & $38-48 \mathrm{~g} / \mathrm{L}$ \\
Lactate dehydrogenase & $970 \mathrm{U} / \mathrm{L}$ & $250-580 \mathrm{U} / \mathrm{L}$ \\
Adjusted prothrombin time & $29.8 \mathrm{~s}$ & $27.0-35.6 \mathrm{~s}$ \\
International normalized ratio & $1.01 \mathrm{~s}$ & $<1.1 \mathrm{~s}$ \\
Peripheral blood film & Unremarkable & - \\
Infection serology & $\mathrm{HBV}$ negative, HCV negative, HIV negative & - \\
Complement & Normal & - \\
Anti-nuclear antibody & Negative & - \\
Electrophoresis & Serum and urine protein electrophoresis & - \\
& were normal & \\
\hline Urine & & - \\
Leucocytes & $14 / \mathrm{HPF}$ & - \\
Erythrocytes & $7 / \mathrm{HPF}$ & - \\
Casts & Not seen & - \\
Crystals & Not seen & $<0.20 \mathrm{~g} / \mathrm{L}$ \\
RBC morphology & $90 \%$ isomorphic; $10 \%$ dysmorphic & \\
24 h urinary protein & $>10 \mathrm{~g} / \mathrm{L}$ & - \\
\hline
\end{tabular}

HBV, hepatitis B virus; HCV, hepatitis C virus; HIV, human immunodeficiency virus; HPF, high-power field; $\mathrm{RBC}$, red blood cell. 


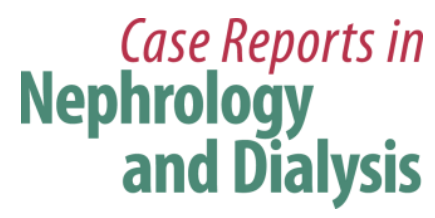

\begin{tabular}{l|l}
\hline Case Rep Nephrol Dial 2018;8:268-276 \\
\hline DOI: 10.1159/000495106 & $\begin{array}{l}\text { @ 2018 The Author(s). Published by S. Karger AG, Basel } \\
\text { www.karger.com/cnd }\end{array}$ \\
\hline
\end{tabular}

Table 2. Reported cases of lumbar artery bleed following percutaneous native renal biopsy

\begin{tabular}{|c|c|c|c|c|c|}
\hline Ref. No. & Biopsy needle; size & Clinical features & Other bleeding sites & Intervention & $\begin{array}{l}\text { Biopsy } \\
\text { pathology }\end{array}$ \\
\hline 4 & $\begin{array}{l}\text { Vim-Silverman biopsy nee- } \\
\text { dle; } 16 \mathrm{G}\end{array}$ & $\begin{array}{l}\text { After } 6 \mathrm{~h} \text {, left loin expand- } \\
\text { ing haematoma; shock }\end{array}$ & $\begin{array}{l}2 \text { puncture sites ooz- } \\
\text { ing blood from kid- } \\
\text { ney lower pole }\end{array}$ & $\begin{array}{l}\text { Angiography failed to identify lumbar } \\
\text { bleed; surgery } 20 \mathrm{~h} \text { later to oversew } \\
\text { lumbar artery }\end{array}$ & $\begin{array}{l}\text { Diabetic kidney dis- } \\
\text { ease, light chain cast } \\
\text { nephropathy }\end{array}$ \\
\hline 5 & $\begin{array}{l}\text { Vim-Silverman biopsy nee- } \\
\text { dle; } 16 \text { G }\end{array}$ & $\begin{array}{l}\text { After } 2 \mathrm{~h} \text {, pain with hypo- } \\
\text { tension }\end{array}$ & $\begin{array}{l}\text { Arteriovenous fistula } \\
\text { in kidney }\end{array}$ & Selective embolization with coil & $\begin{array}{l}\text { Membranous } \\
\text { nephropathy }\end{array}$ \\
\hline 6 & Tru-cut biopsy needle; $16 \mathrm{G}$ & $\begin{array}{l}\text { Immediate pain and hypo- } \\
\text { tension }\end{array}$ & Intra-renal & $\begin{array}{l}\text { First angiography identified intrare- } \\
\text { nal bleed; second angiography } 48 \mathrm{~h} \\
\text { later identified lumbar bleed }\end{array}$ & - \\
\hline 7 & Tru-cut biopsy needle; 16 G & $\begin{array}{l}\text { After } 6 \mathrm{~h} \text {, left loin expand- } \\
\text { ing haematoma; shock }\end{array}$ & $\begin{array}{l}\text { Pseudo-aneurysms } \\
\text { in kidney }\end{array}$ & $\begin{array}{l}\text { Selective embolization with Gelfoam } \\
\text { and metal coil }\end{array}$ & $\begin{array}{l}\text { IgA nephropathy with } \\
\text { crescents }\end{array}$ \\
\hline 8 & $\begin{array}{l}\text { Vim-Silverman biopsy nee- } \\
\text { dle; - } \\
\text { No ultrasound guidance }\end{array}$ & $\begin{array}{l}\text { After } 4 \mathrm{~h} \text {, left loin expand- } \\
\text { ing haematoma; pain }\end{array}$ & - & $\begin{array}{l}\text { Failed angiography, explorative sur- } \\
\text { gery }\end{array}$ & - \\
\hline 9 & Tru-cut biopsy needle; 16 G & $\begin{array}{l}\text { After } 2 \text { weeks, severe left } \\
\text { back pain }\end{array}$ & - & Superselective embolization with coil & $\begin{array}{l}\text { Diabetic } \\
\text { kidney disease }\end{array}$ \\
\hline 10 & Tru-cut biopsy needle; $18 \mathrm{G}$ & $\begin{array}{l}\text { After } 8 \mathrm{~h} \text {, right lumbar hae- } \\
\text { matoma, shock }\end{array}$ & $\begin{array}{l}\text { Renal capsular artery } \\
\text { bleed }\end{array}$ & $\begin{array}{l}\text { Embolization with iopamidol, subse- } \\
\text { quent surgical evacuation due to Page } \\
\text { kidney }\end{array}$ & $\begin{array}{l}\text { Diabetic } \\
\text { kidney disease }\end{array}$ \\
\hline
\end{tabular}

All biopsies were performed with real-time ultrasonographic guidance unless otherwise stated. 